\title{
Method Comparison of DNA Isolation and Quantification for Fish and Seafood Authenticity Determination
}

\author{
Dwiyitno1, Stefan Hoffman², Koen Parmentier², and Chris Van Keer ${ }^{3}$ \\ ${ }^{1}$ Research and Development Center for Marine and Fisheries Product Processing and Biotechnology, \\ Jalan K.S. Tubun, Petamburan VI, Slipi, Jakarta Pusat 10260, Indonesia \\ ${ }^{2}$ Institute for Agricultural and Fisheries Research (ILVO), Ankerstraat 1, Oostende 8400 Belgium \\ ${ }^{3} \mathrm{KU}$ Leuven Technologie Campus Gent, Gebroeders Desmetstraat 1, Gent 9000 Belgium \\ Article history: \\ Received: 11 November 2018; Revised: 2 December 2018; Accepted: 26 December 2018
}

\begin{abstract}
Fish and seafood products has been commonly targeted for fraudulent activities. For that reason, authentication of fish and seafood products is important to protect consumers from fraudulent and adulteration practices, as well as to implement traceability regulation. From the viewpoint of food safety, authenticity is beneficial to protect public from serious food poisoning incidents, such as due to ingestion of toxic species. Since DNA based identification depends on the nucleic acid polymerase chain reaction (PCR), the quantity and quality/purity of DNA will contribute significantly to the species authentication. In the present study, different DNA extraction and purification methods ( 3 classical methods and one commercial kit) were compared to produce the better isolated DNA for PCR amplification. Additionally, different methods for the estimation of DNA concentration and purity which is essential for PCR amplification efficiency were also evaluated. The result showed that classical DNA extraction methods (based on TNES-Urea) yielded a higher amount of DNA (11.30-323.60 ng/g tissue) in comparison to commercial kit/Wizard Promega (5.70-83.45 ng/g tissue). Based on the purity of DNA extract $\left(\mathrm{A}_{260 / 280}\right)$, classical DNA extraction method produced relatively similar on DNA quality compared to the commercial kit (1.79-2.12). Interestingly, all classical methods produced DNA with $\mathrm{A}_{260 / 280}$ ratio of more than 2.00 on the blue mussel, in contrast with commercial kit. The commercial kit also produced better quality of DNA compared to the classical methods, showing the higher efficiency in PCR amplification. NanoDrop is promising as cheap, robust and safe UV-spectrophotometer method for DNA quantification, as well as the purity evaluation.
\end{abstract}

\section{Keywords: seafood authenticity, DNA isolation, polymerase chain reaction, NanoDrop, Picogreen}

\section{Introduction}

The authenticity of fish species and seafood is essential to implement traceability of food products to protect consumers from fraudulent and adulteration (FAO, 2018; Pahl, 2018). Species identification is also beneficial to prevent mislabeling and substitution of some commercially important seafood by others with lower value (Trotta et al., 2005; Cutarelli et al., 2014). Not only do seafood producers but also food inspectors require authenticity to ascertain the species included in their formulations (Di Pinto et al., 2015). Additionally, from the viewpoint of food safety, authenticity could protect public from dangerous food poisoning incidents, due to ingestion of toxic species such as ciguatoxin, tetrodotoxin, shellfish toxins, scombrotoxin, etc (Martinez, James \& Loreal, 2005; Cohen et al., 2009).

Traditionally, identification of fish and seafood is employed based on the morphological characteristics. External features, such as character of the fin, head, scales, teeth, otoliths, and body shape are commonly important organs for fish species identification (FAO, 2013; FishBase, 2018). However, application of the classical method for species classification is limited as many seafood species are not presented in the original features, such as processed fish that undergo subsequent removal of characteristics (head, fins) used for traditional identification. Recently,

${ }^{*}$ Corresponding author.

E-mail: dwiyitno.brkp@kkp.go.id 
identification of fish and seafood species could be performed using DNA or protein sequences. These species-specific markers could overcome the difficulty of traditionally identification method since they could address the modifications of fish constituents during processing. In practice, DNA based identification is more promising as DNA are more stable than protein to various treatments, including thermal process (Milana, Fusari, Rossi \& Sola, 2011; Zhang \& Hanner, 2012). Currently, DNA barcoding has been establishing as a robust, accurate, and cost-effective method for species identification (Clark, 2015; Di Pinto et al., 2015).

The successfulness of species identification based on nucleic acid method, such as polymerase chain reaction (PCR), depends on the quantity and quality/ purity of DNA, purification techniques and PCR amplification. Low amount of DNA or degraded DNA and the presence of PCR inhibitors are common reason to hamper the efficiency of PCR amplification, especially long sequences or other PCR fingerprint methods (Hu, Liu, Yi \& Huang, 2015; Ai et al., 2016; Chowdhury et al., 2016). Instead of classical method, commercial kit has shown advantages for DNA extraction. Most of classical DNA extraction methods employ TNES digestion buffer containing Tris- $\mathrm{HCl}$, $\mathrm{NaCl}$, EDTA, Sodium Dedocyl Sulphate. In practice, this method is modified in the application of proteinase$\mathrm{K}$, RNAse and precipitation solution that produce different DNA concentration and purity (Asahida, Kobayasi, Saitoh \& Nakayama, 1996; Wasko, Martins, Oliveira \& Foresti, 2003; Hsieh, Chai \& Wang, 2005).

The present study aimed to evaluate different DNA extraction and purification methods suitable for fish and seafood products. The quantity and purity of DNA were then measured to compare the different quantification methods. With regards to classical spectrofluorometic method, a simple UVspectrophotometric offers a rapid and safe method for measuring DNA concentration and purity (Ganske, 2014; LGC, 2018). Furthermore, PCR amplification of cytochrome- $b$ gene was applied for fish and seafood authenticity test since mitochondrial DNA has been widely used for species identification (Ratnasingham \& Hebert, 2011; Cutarelli et al., 2014; Ai et al., 2016).

\section{Materials and Methods}

A number of 5-10 individual of 4 species of seafood were used for the present study i.e. two fish species (common sole/Solea solea and whiting/Trisopterus luscus), one species of crustacean (brown shrimp/ Crangon crangon) and mollusk (blue mussel/Mitylus edulis). Prior to DNA extraction, all species were identified based on their morphological features in comparison to the reference (FishBase.org). All samples were then eviscerated and filleted to obtain the tissue for DNA extraction. Further step was DNA extraction using three classical methods and a commercial kit. The isolated DNA was then evaluated to measure the concentration and purity. Two methods for DNA quantification was compared i.e. spectrophotometric and fluorospectrometric methods. The DNA purity was also estimated based on spectrophotometric method and gel electrophoresis. To evaluate the DNA efficiency on fish authenticity determination, PCR evaluation was performed on cytochrome- $b$ gene of mitochondrial DNA.

\subsection{DNA Extraction}

DNA was extracted and purified by using a commercial kit and classical methods. Wizard Genomic Purification kit, originate from Promega was used as a commercial method (method 1). Additionally, the three classical methods employed based on the use of TNES buffer for cell lysis and phenol-chloroform for the DNA extraction according to the procedure described by Hsieh et al., 2005 (method 2); Wasko et al., 2003 (method 3) and Asahida et al., 1996 (method 4). These classical methods have been widely used to extract DNA either for fish tissue, fin, scales, or other food products. The resulting DNA was then quantified based on their quantity and purity. In general, the differences among the DNA isolation method is in the application of lysis buffer, RNAse, protein precipitation and DNA recovery steps as presented in Table 1. Furthermore, the DNA was tested for PCR amplification.

\subsubsection{DNA extraction method 1 (Wizard Promega)}

DNA extraction and purification were performed based on a commercial kit (Promega, 2002). In a 1.5 $\mathrm{ml}$ tube, $120 \mu \mathrm{l}$ of a $0.5 \mathrm{M}$ EDTA-pH 8.0 was added to $600 \mu \mathrm{l}$ of nuclei lysis solution (NLS). Each tube was added with approximately $100 \mathrm{mg}$ of tissue followed by adding $17.5 \mu \mathrm{l}$ of $20 \mathrm{mg} / \mathrm{ml}$ Proteinase-K. The tube was then vortexed gently for 20 seconds, incubated overnight at $55^{\circ} \mathrm{C}$. After the incubation, $3 \mu \mathrm{l}$ of $4 \mathrm{mg} /$ $\mathrm{ml}$ RNAse was added to the nuclear lysate and incubated at $37^{\circ} \mathrm{C}$ for 30 minutes.

A $200 \mu$ l of protein precipitation solution (PPS) was added to extract the DNA. The crude extract was then vortexed and further centrifugation at $14.000 \mathrm{rpm}$ for 10 minutes. The supernatant was transferred in to a new tube containing $600 \mu \mathrm{l}$ of IPA and freezed at $-20 \stackrel{\circ}{ } \mathrm{C}$ for 1 hour. The DNA was precipitated at 14.000 rpm centrifugation for 10 minutes. The DNA pellet was 
Table 1. Basic protocol of the different DNA extraction methods

\begin{tabular}{lcccc}
\hline \multicolumn{1}{c}{ Step } & $\begin{array}{c}\text { Method 1 } \\
\text { (Promega) }\end{array}$ & $\begin{array}{c}\text { Method 2 } \\
\text { (Hsieh et al., 2005) }\end{array}$ & $\begin{array}{c}\text { Method 3 } \\
\text { (Wasko et al., 2003) }\end{array}$ & $\begin{array}{c}\text { Method 4 } \\
\text { (Asahida et al., 1996) }\end{array}$ \\
\hline Lysis Buffer & NLS & TNES: 1\% SDS & $\begin{array}{c}\text { TNES-Urea: 0.5\% SDS, } \\
\text { 4M Urea }\end{array}$ & $\begin{array}{c}\text { TNES-Urea: 1\% SDS, } \\
6 \mathrm{M} \text { Urea }\end{array}$ \\
Proteinase-K & $350 \mu \mathrm{g}$ & $300 \mu \mathrm{g}$ & $300 \mu \mathrm{g}$ & $40 \mu \mathrm{g}$ \\
RNAse & $12 \mu \mathrm{g}$ & - & $300 \mu \mathrm{g}$ & $12 \mu \mathrm{g}$ \\
Protein & $200 \mu \mathrm{L} \mathrm{PPS}$ & $600 \mu \mathrm{L} \mathrm{PCl}$ & $4 \mathrm{~mL} \mathrm{PCl}$ & $600 \mu \mathrm{L} \mathrm{PCl,}$ \\
Precipitation & & & & $600 \mu \mathrm{L} \mathrm{Cl}$ \\
DNA Recovery & $600 \mu \mathrm{L} \mathrm{IPA}$ & $600 \mu \mathrm{LEtOH}+\mathrm{NaOAC}$ & $600 \mu \mathrm{L} \mathrm{EtOH}$ & $600 \mu \mathrm{LEtOH}$ \\
& & $3 \mathrm{M}$ & $+\mathrm{NaCl} 1 \mathrm{M}$ & $+\mathrm{NaOAc} \mathrm{3M}$ \\
\hline
\end{tabular}

Note:

NLS: Nuclei lysis solution + 0.5 M EDTA, pH 8

TNES: $10 \mathrm{mM}$ Tris $\mathrm{HCl}, \mathrm{pH} 8 ; 125 \mathrm{mM} \mathrm{NaCl}$; $10 \mathrm{mM}$ EDTA; SDS (Sodium Dodecyl Sulphate)

PCl: Phenol: Chloroform: Isoamylalcohol (25:24:1); PPS (Protein Precipitation Solution)

$\mathrm{NaOAc}$ : sodium acetate $\mathrm{pH}$ 5.3; $\mathrm{NaCl}$ : Sodium chloride

EtOH: Ethanol; IPA: Isopropyl alcohol

washed by $600 \mu$ l of $70 \%$ ethanol, followed air dried and re-suspended in $100 \mu \mathrm{l}$ TE buffer and incubated at $65^{\circ} \mathrm{C}$ for 1 hour for further application.

\subsubsection{DNA extraction method 2 (Hsieh et al., 2005)}

The difference of this method from the other DNA extraction methods is the use of TNES buffer without urea as well as RNase. Approximately $100 \mathrm{mg}$ of tissue was crushed with $600 \mu \mathrm{l}$ buffer in a $1.5 \mathrm{ml}$

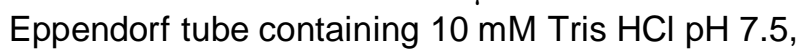
$125 \mathrm{mM} \mathrm{NaCl}, 10 \mathrm{mM}$ EDTA, and $1 \%$ SDS. The tube was added with $15 \mu \mathrm{l}$ of $20 \mathrm{mg} / \mathrm{ml}$ Proteinase- $\mathrm{K}$ followed by overnight incubation at $55^{\circ} \mathrm{C}$.

Protein precipitation was performed by $600 \mu$ of phenol:chloroform:isoamyl alcohol (25:24:1). The undissolved material was separated by centrifugation at $14.000 \mathrm{rpm}$ for 10 minutes. The top layer was then collected and transferred to a new tube followed by another extraction with $600 \mu$ of phenol:chloroform (24:1). DNA precipitation was performed in $3 \mathrm{M} \mathrm{NaOAC}$ $\mathrm{pH} 5.3$ and two volume of absolute ethanol and cooled at $-20^{\circ} \mathrm{C}$ for one hour. After centrifugation at 14.000 rpm for 10 minutes, the DNA pellet was rinsed in $600 \mu \mathrm{l}$ of $70 \%$ ethanol, air dried and re-suspended in $100 \mu \mathrm{l}$ of TE buffer and incubated at $65^{\circ} \mathrm{C}$ for 1 hour.

\subsubsection{DNA extraction method 3 (Wasko et al., 2003)}

One hundred milligrams of fresh tissue was transferred in to a $15 \mathrm{ml}$ falcon tube containing $4 \mathrm{ml}$
TNES-Urea buffer (4 M urea; $10 \mathrm{mM}$ Tris $\mathrm{HCl}$, $\mathrm{pH} 7.5$; $125 \mathrm{mM} \mathrm{NaCl} ; 10 \mathrm{mM}$ EDTA; $0.5 \%$ SDS). The tube was added with $15 \mu \mathrm{l}$ of $20 \mathrm{mg} / \mathrm{ml}$ RNAse and incubated at $42{ }^{\circ} \mathrm{C}$ for 1 hour. A $75 \mu \mathrm{l}$ of $4 \mathrm{mg} / \mathrm{ml}$ Proteinase- $K$ was added to each tube followed by second incubation at $42{ }^{\circ} \mathrm{C}$ for 10 hours.

The protein was isolated with $4 \mathrm{ml}$ of phenol:chloroform:isoamyl alcohol (25:24:1) and the tubes were rotated at $14.000 \mathrm{rpm}$ for 10 minutes. The top layer was collected and transferred to a new tube. DNA recovery was in $1 \mathrm{M} \mathrm{NaCl}$ and two volume of absolute ethanol, followed by centrifugation at 14.000 rpm for 10 minutes. The DNA was rinsed in $70 \%$ ethanol, air dried and re-suspended in TE buffer by incubation at $65^{\circ} \mathrm{C}$ for 1 hour.

\subsubsection{DNA extraction method 4 ( Asahida et al., 1996)}

Approximately $100 \mathrm{mg}$ of tissue was prepared and transferred into a $1.5 \mathrm{ml}$ Eppendorf tube. A $600 \mu \mathrm{l}$ of TNES-Urea buffer ( $6 \mathrm{M}$ urea; $10 \mathrm{mM}$ Tris $\mathrm{HCl}, \mathrm{pH} 7.5$; $125 \mathrm{mM} \mathrm{NaCl} ; 10 \mathrm{mM}$ EDTA; $1 \%$ SDS) was used as the extraction buffer. For tissue digestion, the tube was added with $2 \mu \mathrm{l}$ of $20 \mathrm{mg} / \mathrm{ml}$ Proteinase- $\mathrm{K}$ and incubated overnight at $37^{\circ} \mathrm{C}$. A $3 \mu$ of RNAse was added to the tubes and the incubation was maintained at $37^{\circ} \mathrm{C}$ for 30 minutes.

The DNA was extracte by adding $600 \mu \mathrm{l}$ of phenol:chloroform:isoamyl alcohol (25:24:1), followed by centrifugation at $14.000 \mathrm{rpm}$ for 10 minutes. The top layer was collected and transferred to a new tube for further extraction using $600 \mu \mathrm{l}$ chloroform:isoamyl 
alcohol (24:1). After centrifugation, the top layer was re-collected and transferred into a new tube.

A $1 / 10$ volume of $\mathrm{NaOAc} 3 \mathrm{M}, \mathrm{pH} 5.3$ and 2 volume of $99 \%$ ethanol was added to the tube for DNA precipitation and gently inverted. After stored at $20 \stackrel{\circ}{ } \mathrm{C}$ for 1 hour, the tube was rotated at $14.000 \mathrm{rpm}$ for 10 minutes. The DNA pellet was rinsed in $70 \%$ ethanol followed by air dried and re-suspended in 100 $\mu$ l of TE buffer ( $10 \mathrm{mM}$ Tris HCl pH8.0; $1 \mathrm{mM}$ EDTA pH $8)$, incubated at $65^{\circ} \mathrm{C}$ for 1 hour.

\subsection{Determination of DNA Concentration and Purity}

Two different spectrophotometric methods (fluorospectrometric using Picogreen and UVspectrophotometric method using NanoDrop) were evaluated for measuring the DNA concentration and purity of the different samples. A Shimadzu Fluorospectrophotometer - RF1501 was applied to measure the fluorescent index of dsDNA. In a $4.5 \mathrm{ml}$ disposable cuvette (ROTH; Art.8128), one microliter of isolated DNA was diluted in $1.997 \mu \mathrm{l}$ of sterilized TE buffer. Two microlitres of fluorescent dye of QuantT Picogreen dsDNA (Invitrogen) was added to bind the double-stranded DNA. After incubated for 5 minutes at dark room, samples were measured at wavelength of $480 \mathrm{~nm}$ excitation and $520 \mathrm{~nm}$ emission. A standard curve was created by $2 \mu \mathrm{g} / \mathrm{ml}$ of Lambda DNA (Invitrogen) as a working solution. A seven-point standard curve was designed by diluting working solution in the same way as the experimental sample. The fluorescent values were then subtracted to the reagent blank; the data was used to generate the standard curve of fluorescent against DNA concentration of the samples.

In comparison to Spectrofluorometric method, the concentration and purity of DNA were also estimated by UV-spectrophotometric method. A NanoDrop ND1000 spectrophotometer (Desjardin \& Conklin, 2010) was used to measure DNA concentration and the absorbance ratio at 260 and $280 \mathrm{~nm}$. A $1 \mu \mathrm{l}$ sample was pipetted onto the lower pedestal of NanoDrop apparatus. The instrument is controlled by integrated software run from PC that measures not only DNA concentration but also the purity by acquiring the ratio of $A_{260 / 280^{\circ}}$.

In order to evaluate the size and purity of DNA fragments, isolated DNA was performed in an agarose gel electrophoresis. One percent of agarose (Promega) was dissolved in 1XTAE buffer with SybrGold gel stain (Molecular Probes). The mixture was then heated in a microwave for 3-5 minutes until the agarose completely dissolved. Afterward, the gel was poured into a gel mold with casting combs in place. The gel was allowed to solidify for 20-30 minutes in a chamber of Midicell ${ }^{\circledast}$ Primo EC 330 (Thermo). The reservoir was filled with $1 \times$ TAE buffer until the agarose gel was just covered by the buffer. Five microliters of samples containing blue-orange loading dye (Promega) was loaded into the gel. As the fragment marker, a Smart Ladder 1800 (Eurogentec) was used. Electrophoresed was run for one hour at 66 volt and DNA fragments were visualized on a UV trans-illuminator $(254 \mathrm{~nm})$ and captured by Edas-290 digital camera (Kodak).

\subsection{PCR Assays}

The isolated DNA was analyzed by PCR to evaluate the suitability for amplification. The primer pair used in this study included forward primer of CytBL1 and reverse primer of $\mathrm{CytBH}$ with the target of $357 \mathrm{bp}$ fragment of cytochrome-b gene. These primers were employed previously by Bartlett and Davidson (1991) for the identification of tuna species. Additionally, Cespedes et al. (1998) studied the same primer, with different condition on PCR amplification, for species identification of flat fish. The set of primers are:

Cyt BL1 : 5'- CCA TCC AAC ATC TCA GCA TGA TGA AA - 3' (26mers)

\section{Cyt BH : 5'- CCC CTC AGAATG ATA TTT GTC CTC A -3 ' (25mers)}

The reaction was performed in a final volume of $20 \mu \mathrm{l}$ using a JumpStart REDTaq ReadyMix P 0982 (Sigma), each primer and serial dilution of DNA templates as follows:

\begin{tabular}{lcc}
\hline \multicolumn{1}{c}{ Reagent } & Volume $(\boldsymbol{\mu l})$ & $\begin{array}{c}\text { Final } \\
\text { concentration }\end{array}$ \\
\hline $\begin{array}{l}\text { 2x JumpStart REDTaq } \\
\text { ReadyMix }\end{array}$ & $10 \mu \mathrm{l}$ & $1 \mathrm{x}$ \\
Forw ard primer (Cyt BL1) & $2 \mu \mathrm{l}(10 \mathrm{mM})$ & $1 \mu \mathrm{M}$ \\
Reverse primer (Cyt BH) & $2 \mu \mathrm{l}(10 \mathrm{mM})$ & $1 \mu \mathrm{M}$ \\
DNA template & variable & $5-20 \mathrm{ng}$ \\
$\mathrm{PCR} \mathrm{H}_{2} \mathrm{O}$ & variable & - \\
\hline
\end{tabular}

\begin{tabular}{lll}
\hline Total volume & $20 \mu \mathrm{l}$ & - \\
\hline
\end{tabular}

Amplification was performed in a PCR-express thermal cycler (Hybaid). PCR amplification was carried out for 35 cycles with conditions in the following steps: 1. Initiation at $94^{\circ} \mathrm{C}$ for 8 minutes $(1 \mathrm{x}) ; 2$. Denaturation at $94{ }^{\circ} \mathrm{C}$ for 30 seconds $(35 \mathrm{x})$; 3 . Annealing at $50^{\circ} \mathrm{C}$ for 30 seconds $(35 \mathrm{x})$; 4 . Extension at $72^{\circ} \mathrm{C}$ for 1 minute $(35 \mathrm{x})$; and 5 . Final extension at $72{ }^{\circ} \mathrm{C}$ for 4 minutes $(1 \mathrm{x})$.

The PCR product was visualized by gel electrophoresis on $2.0 \%(\mathrm{w} / \mathrm{v})$ of agarose (Promega) GelRed staining. The gel preparation was the same as the electrophoresis of DNA extract. Five $\mu$ l aliquot 
of amplified products were then loaded on the gel together with $100 \mathrm{bp}$ DNA ladder (Eurogentec) as the marker. DNA fragments were recorded on a UV transilluminator $(254 \mathrm{~nm})$ and captured by Edas-290 digital camera.

\section{Results and Discussion}

\subsection{DNA Concentration and Purity}

The DNA concentration and purity performed by the different extraction methods are shown in Figure 1. It was found that all extraction methods gave positive result of isolated DNA. Typically, the classical extraction methods (method 2, 3, and 4) produced higher DNA yield on all samples i.e. $11.30-178.20 \mathrm{ng} /$ $\mathrm{g}$ fish tissue, $23.80-322.64 \mathrm{ng} / \mathrm{g}$ crustacean tissue and 208.40-323.60 $\mathrm{ng} / \mathrm{g}$ mollusk tissue in comparison to commercial kit/method 1 (5.70-12.59 ng/g fish tissue, $10.4-28.62 \mathrm{ng} / \mathrm{g}$ crustacean tissue and 54.40 $83.45 \mathrm{ng} / \mathrm{g}$ mollusk tissue). It was found that different samples produced different DNA concentration. Fish species of $T$. luscus yielded the lowest DNA concentration (7.5-63.3 ng/mg tissue), while blue mussel/M. edulis produced the highest one (54.40$323.60 \mathrm{ng} / \mathrm{mg}$ tissue). The concentration of DNA measured by spectrometric method corresponds to the result of the gel electrophoresis evaluation of DNA extracts, indicated by relatively weaker bands on method 1 and 2 compared to that of method 3 and 4 (Figure 3).
The application of higher concentration of lysis solution resulted in the more degradation of isolated DNA, particularly on T. luscus and $M$. edulis, as performed in gel electrophoresis profile (Figure 3 ). This phenomenon takes place as the tissue of $T$. luscus and $M$. edulis is apparently less compact than that of $S$. solea and C. crangon. For that reason, $1 \%$ SDS without urea (Method 2) or $0.5 \%$ SDS with urea $4 \mathrm{M}$ (Method 3), is likely sufficient for cell lysis of fish and seafood products. In addition, the lysis buffer with $1 \%$ SDS in the presence of $6 \mathrm{M}$ urea (method 4) produced more degraded DNA as performed by the electrophoresis profile of DNA integrity. This combination of lysis buffer is apparently more applicable for fin and scale specimen instead of tissue, as described by Asahida et al. (1996) and Wasko et al. (2003).

Based on the $A_{260 / 280}$ ratio (Figure 2), all extraction methods produced relatively high purity of DNA, ranging between 1.89 and 2.12. In general, the $A_{260 / 280}$ of pure DNA is between 1.80 and 2.00 (Brescia, 2012). The result of the classical extraction methods revealed that the yield of DNA depends on the concentration of lysis solution (SDS and urea) and enzymes (Proteinase and RNAse). SDS with the presence or absence of urea is important for cell disruption to release the DNA. In addition, Proteinase contributes in protein digestion while RNA is degraded by RNase. Evaluation of $A_{260 / 280}$ showed that all extraction methods produced high purity of isolated DNA; correspond to the results described by Wasko et al. (2003) and Di Pinto et al. (2007). Besides protein and

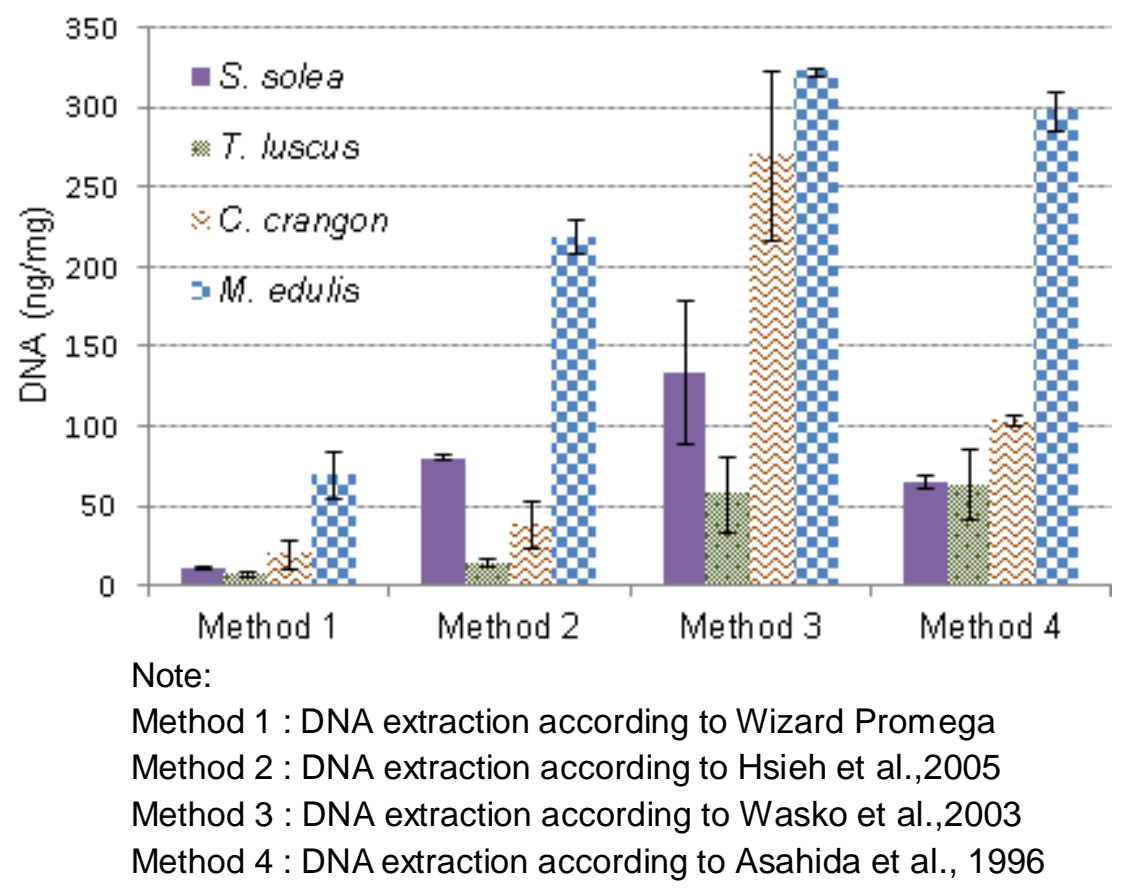

Figure 1. DNA concentration performed by different extraction methods on fish, crustacean, and mollusk 


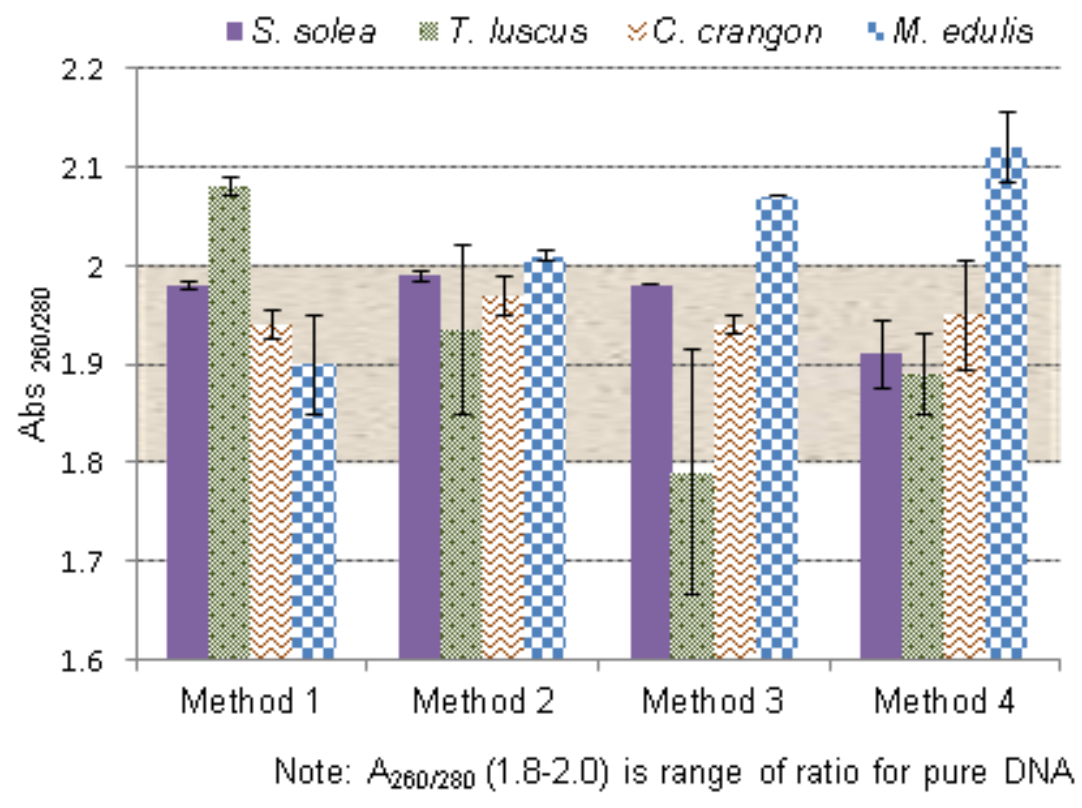

Note:

Method 1 : DNA extraction according to Wizard Promega

Method 2 : DNA extraction according to Hsieh et al.,2005

Method 3 : DNA extraction according to Wasko et al.,2003

Method 4 : DNA extraction according to Asahida et al., 1996

Figure 2. DNA purity $\left(A_{260 / 28}\right)$ performed by different extraction methods on fish, crustacean and mollusk samples

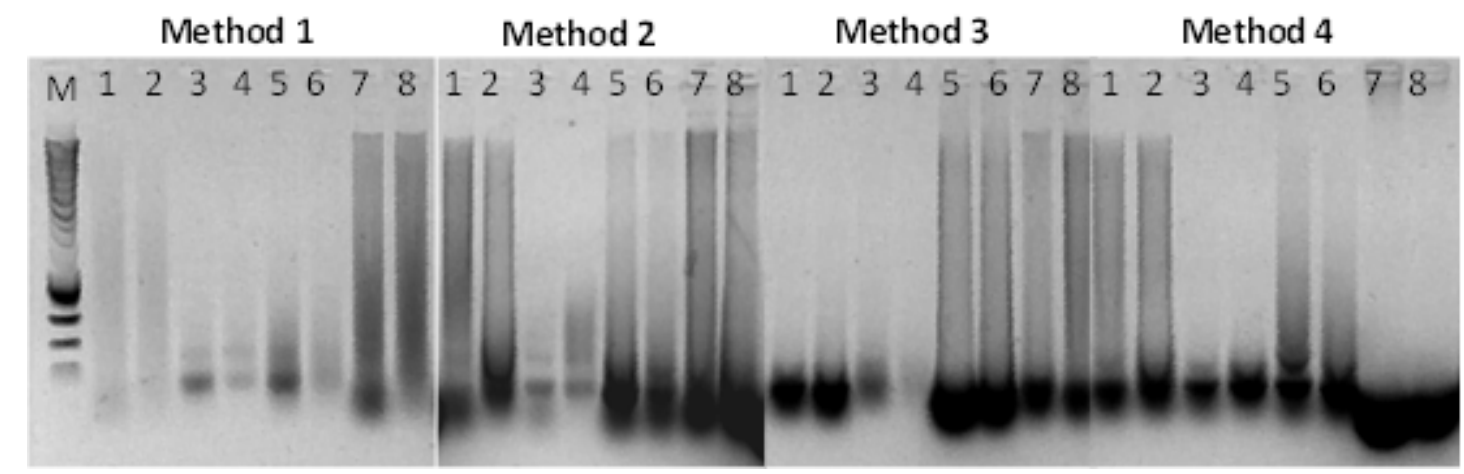

1-2: S. solea; 3-4: T. Iuscus; 5-6: C. crangon; 7-8: M. edulis; M: DNA marker 1kb

Figure 3. Gel electrophoresis profile of isolated DNA on fish, crustacean and mollusk

RNA, phenol and salt are common contaminants present in the DNA extracted by classical methods.

The result revealed that the yields of DNA depend on the concentration of lysis solution (SDS and/or urea) and both enzyme of proteinase and RNAse. Based on the ratio of absorbance at 260 and $280 \mathrm{~nm}$, all extraction methods produced a relatively high purity of DNA extract (Wasko et al., 2003 \& Di Pinto et al., 2007). Protein and phenol are among the most components to reduce the purity of DNA isolate due to improper preparations. Protein may present due to un-optimized precipitation, while phenol was used during DNA extraction together with chloroform and isoamyl alcohol. In general methods 2 of Hsieh et al. (2005) produced a better DNA purity, indicated by the ratio of $A 260 / 280$ between 1.8 and 2.0 for all tested species of fish, crustacean and mollusk (Figure 2), while method 1 of commercial kit Promega produced relatively better DNA purity than method 3 and $4 . A_{260 /}$ ${ }_{280}$ ratio of DNA under 1.8 indicates protein 


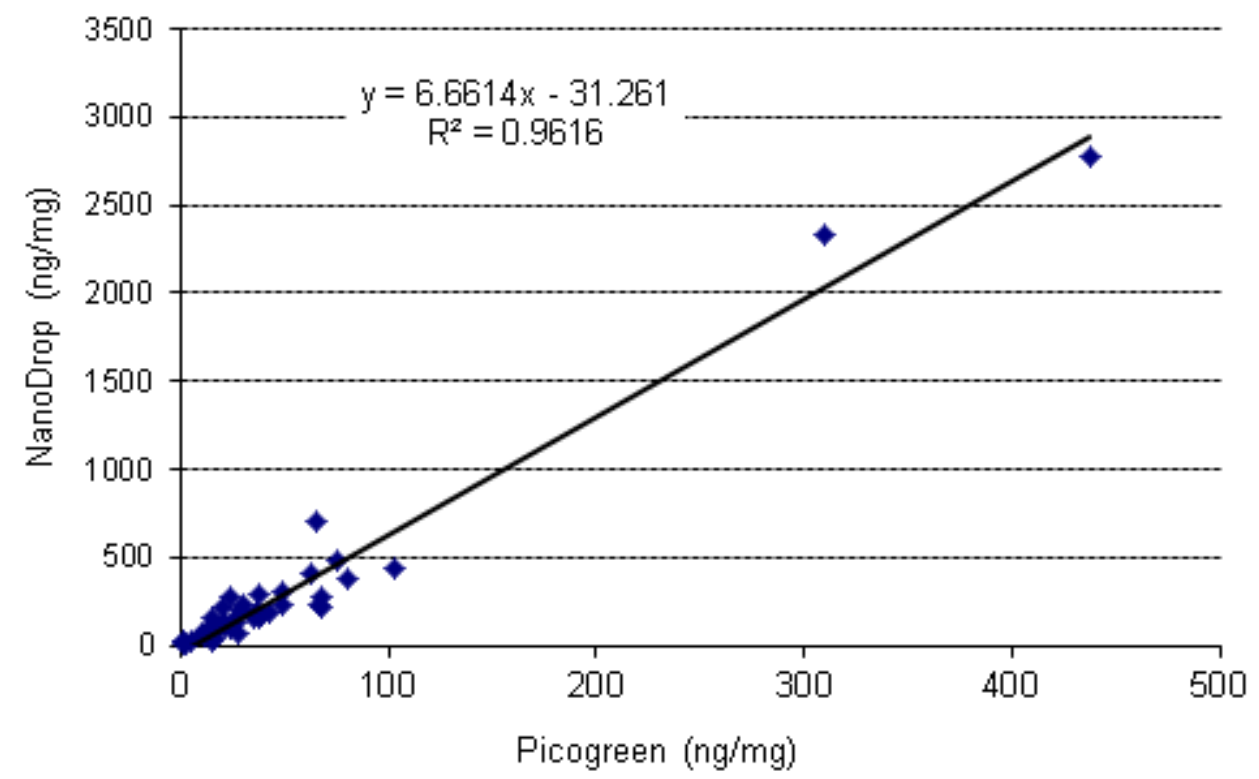

Figure 4. Correlation of DNA concentration measured by Picogreen and NanoDrop

contamination, while ratio over 2.0 indicates potential contamination of extraction residue such as RNA, phenol, alcohol, and salts (Brescia, 2012).

The application of different solution for DNA recovery might also influence the DNA purity. Since commercial kit only used IPA without sodium salt, this method may reduce the DNA recovery. However, the absence of sodium salt would also reduce the possible salt contamination in the final product. In contrast, all classical method used ethanol with combination of $\mathrm{NaOAC}$ or $\mathrm{NaCl}$ to increase DNA recovery. Consequently, salt impurities may also present in the final DNA extract. IPA is known to be more efficient in DNA recovery compare to ethanol due to lower dielectric constant, which is also beneficial to precipitate salt impurities. In contrast, ethanol is more volatile than IPA and therefore the DNA will dry faster. The application of $\mathrm{NaOAc}$ is more effective for DNA recovery due to more soluble in IPA or ethanol than $\mathrm{NaCl}$. However, $\mathrm{NaCl}$ has advantages if sample contains SDS residue from the previous step of cell lysis (Maniatis, Fritsch \& Sambrook, 1982).

Even though yielded lower amount of isolated DNA, commercial kit (Promega) produced less fragmented DNA. Producing the less degraded DNA is essential for the PCR application of long fragmented DNA (Weder, 2002; Di Pinto et al., 2007). The more contaminated DNA performed by method 4 may be associated with the use of relatively low concentration of Proteinase and RNAse in comparison to the other methods, as performed by a relatively high of $A_{260 / 280}$ ratio on $T$. luscus and $M$. edulis (Figure 4) and electrophoresis profile of DNA isolates (Figure 3). The combination of Proteinase and buffer component is critical to denature DNAse which can contribute to reducing cellular integrity. Technically, cationic ions (such as $\mathrm{Mg}^{2+}, \mathrm{Ca}^{2+}$ ) which are important for DNAse can be chelated by EDTA present in lysis buffer (Brescia, 2012). Importantly, DNA extraction by commercial kit offers a convenient way as it is simple and can avoid the use of phenol-chloroform.

\subsection{Evaluation of Determination Method for DNA Concentration and Purity}

In the present study, the UV-Vis absorption spectra of DNA concentration were recorded by a NanoDrop ${ }^{\circledR}$ ND-1000 spectrophotometer (Isogen). This device has a full-spectrum between 220 and $750 \mathrm{~nm}$ that measures only approximately $1 \mu \mathrm{l}$ samples. This eliminates the need for consumable cuvettes and other sample preparation devices as performed in a spectrofluorometer. NanoDrop is also known as robust, less harmful and more environmental friendly application since the measure does not require additional DNA staining as performed in spectrofluorometer method. Not only measure the DNA concentration, but also does NanoDrop in parallel measure the absorbance ratio which is beneficial to estimate the DNA purity.

Based on the correlation test as presented in Figure 4, a UV-Vis spectrometry based (NanoDrop) measurement likely overestimates DNA concentration nearly 7 times higher in comparison to that of spectrofluorometry based measurement (Picogreen). This could be explained as the major limitation of this method are the contribution of nucleotides and singlestranded DNA to the signal, the interference caused 


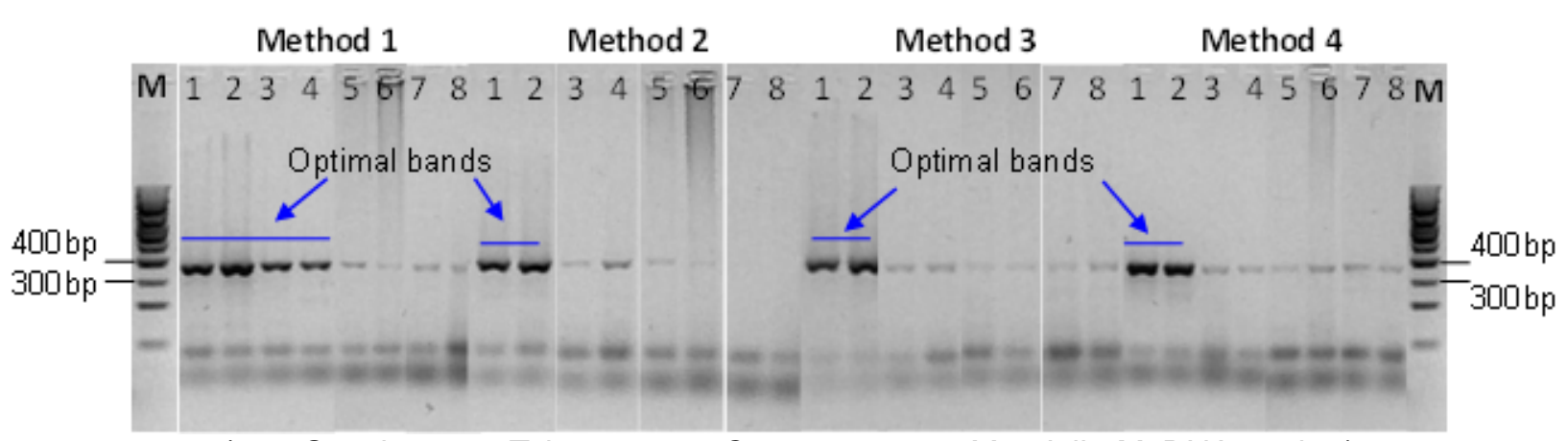

(1-2: S. solea; 3-4: T. Iuscus; 5-6: C. crangon; 7-8: M. edulis; M: DNA marker)

Figure 5. Electrophoresis profile of PCR products following the different DNA extractions

by contaminants due to inappropriate preparations, and the inability to distinguish between DNA and RNA. However, spectrophotometry is a common method for measuring DNA concentration due to the simplicity and less cost. Spectrophotometer technique measures DNA based on the determination of absorbance at $260 \mathrm{~nm}$, which also absorbs protein impurities.

Generally, the detection limit of classical spectrophotometer is quite high $(5 \mu \mathrm{g} / \mathrm{ml}$ dsDNA solution), compared to that of spectrofluorometer approx. $10 \mathrm{ng} / \mathrm{ml}$ (Paul \& Myers, 1982). Certain dye even demonstrates a detection limit up to $25 \mathrm{pg} / \mathrm{ml}$ (Invitrogen, 2007). Fluorometric method also less consumes DNA sample, as only $1 \mu \mathrm{l}$ is needed for the measurement compare to at least $10 \mu \mathrm{l}$ on spectrophotometer method. Interestingly, fluorometric method is suitable for selective targets, dsDNA, ssDNA or RNA, with less interference. With regard to NanoDrop, this UV-Vis measurement method could reduce the disadvantages of UV-Vis spectrometry, in term of either sample requirement or detection limit. Currently common detection limit of NanoDrop is 2 $\mu \mathrm{g} / \mathrm{ml}$ with 1-2 $\mu$ l DNA sample for each measurement. Interestingly, the result of DNA purity measured by NanoDrop (Figure 2) corresponds to the result of gel electrophoresis test (Figure 3). Therefore, application of NanoDrop would reduce the time significantly and cost for DNA concentration and purity measurement compared to classical spectrofluorometric measurement.

\subsection{PCR Assay}

Electrophoresis evaluation of PCR assay resulted by the different DNA extraction methods gave a positive result as presented in Figure 5. All isolated DNA prepared by the different extraction methods were amplified targeted DNA fragment to generate a 360 bp of cytochrome-b gene. DNA extract performed by commercial kit (Promega) resulted in the better amplified product as demonstrated the stronger bands on the T. Iuscus sample compared to that of other methods. Remarkably, amplified products of $S$. solea produced a strong band on all extraction methods. More concentration of DNA template per PCR reaction seems to be required for the optimum amplification of $T$. luscus isolate, instead of $5 \mathrm{ng}$ as for $S$. solea sample.

Specifically, a weak band was performed on all amplified products of crustacean sample (C. crangon) and mussel sample (M. edulis). Optimal amplification might not be achieved yet due to inappropriate primers, amplification condition or the present of PCR inhibitors. Originally, the primers used in the present study (cytBL1 and cytBH) were employed to amplify tuna species (Bartlett \& Davidson, 1991) and flat fish (Cespedes et al., 1998). Specifically, the invisible band of blue mussel fragment on PCR of method 2 might be affected by PCR inhibitors. Earlier study showed that some PCR inhibitors such as glycogen, algae and other micro biota present in bivalve-mollusk samples since they are known as filter feeding species (Schrader, Schielke, Ellerbroek, \& Johne, 2012). Additionally, the absent of urea and RNAse application in method 2 might also contribute in reducing the DNA purity of blue mussel as the $A_{260 / 280}$ was over 2.00, indicating minor contamination.

\section{Conclusion}

Typically, classical DNA extraction methods yielded a higher amount of DNA extract (11.30-323.60 $\mathrm{ng} / \mathrm{g}$ tissue) in comparison to commercial kit/Promega (5.70-83.45 ng/g tissue). Based on the purity of DNA extract $\left(A_{260 / 280}\right)$, both methods (commercial kit and classical method) produced relatively high DNA quality $\left(A_{260 / 280}=1.79-2.12\right)$. All classical methods produced DNA with $A_{260 / 280}$ ratio more than 2.00 on blue mussel sample, in contrast with commercial kit. Among classical methods, method 2 and method 3 
demonstrated the less degraded DNA extract. NanoDrop is promising as cheap, robust and safe UVspectrofotometer method for DNA quantification, as well as for DNA purity evaluation. In comparison to spectrophotometer, fluorometric method has higher sensitivity of the assay and therefore tends to produce more accurate dsDNA concentration. Despite yielding lower DNA concentration, the commercial kit (Promega) produced a better quality of DNA isolate compared to the classical methods. In addition, commercial kit offers a simpler procedure and avoids the use of harmful reagents in comparison to classical methods. Among classical DNA isolation methods evaluated in this study, $4 \mathrm{M}$ urea in combination with $0.5 \%$ SDS (method 3 ) or $1 \%$ SDS without urea (method 2) proved to be the optimal lysis solution for fish and seafood products. It is important to note of possible environmental contaminants when the classical DNA extraction method is applied for certain samples, such as bivalvemollusk and consequently require modification of DNA extraction protocol.

\section{Acknowledgement}

The authors acknowledge the Institute for Agriculture and Fisheries Research (ILVO), Oostende-Belgium for the financial support and laboratory facilities. Special thanks to Daphne Deloof for the laboratory assistance during the present study.

\section{References}

Ai, J., Wang, X., Gao, L., Xia, W., Li, M., Yuan, G., Niu, J. \& Zhang, L. (2016). PCR-fingerprint profiles of mitochondrial and genomic DNA extracted from Fetus cervi using different extraction methods. Mitochondrial DNA Part A, 1-7. DOI: 10.1080/ 24701394.2016.1186666.

Asahida, T., Kobayashi, T., Saitoh, K. \& Nakayama, I. (1996). Tissue preservation and total DNA extraction from fish stored at ambient temperature using buffers containing high concentration of urea. Journal of Fish Science, 62, 727-730.

Bartlett, S.E. \& Davidson, W.S. (1991). Identification of Thunnus tuna species by the polymerase chain reaction and direct sequence analysis of their mitochondrial cytochrome b genes. Journal of Fisheries \& Aquatic Science, 48, 309-317.

Brescia, P. (2012). Micro-Volume Purity Assessment of nucleic acids using A260/A280 ratio and spectral scanning. Application Note: protein and nucleic acid quantifcation. AN060112_12, Rev. 06/04/12. BioTek Instruments, Inc., Winooski, VT. Retrieved from http:// www.biotek.com

Clark LF. 2015. The current status of DNA barcoding technology for species identification in fish value chains. Food Policy, Vol: 54: 85-94
Céspedes, A., Garcia, T., Carrera, E., Gonzalez, I., Sanz, B., Hernandez, P.E., \& Martin, R. (1998). Identification of flatfish species using polymerase chain reaction (PCR) amplification and restriction analysis of the cytochrome b gene. Journal of Food Science, 63, 206-209.

Chowdhury, M.M., Rahman, A.S.M.S., Nahar, L., Rahman, M., Al Reza, H., \& Ahmed, M.S. (2016). Efficiency of different DNA extraction methods for fish tissues: A comparative analysis. IOSR Journal of Pharmacy \& Biologocal Science, 11(3), 11-15. doi: 10.9790/3008-1103041115.

Cohen, N.J., Deeds, J.R., Wong, E.S., Hanner, R.H., Yancy, H.F., White, K.D., Thompson, T.F., Wahl, M., ... Gerber, S.I. (2009). Public health response to puffer fish (tetrodotoxin) poisoning from mislabeled product. Journal of Food Protection, 72(4): 810-817.

Cutarelli. A., Amoroso, M.G., de Roma, D., Girardi, S., Galiero, G., Guarino, A., \& Corrado, F. (2014). Italian market fish species identification and commercial frauds revealing by DNA sequencing. Journal of Food Control, 37(1), 46-50

Desjardins, P., \& Conklin, D. (2010). Nanodrop microvolume quantitation of nucleic acids. Journal of Visualized Experimental, 45, e2565. doi : 10.3791/ 2565.

Di Pinto, A., Forte, V.T., Guastadisegni, V.C., Martino, C., Schena, F.P., \& Tantillo, G. (2007). A comparison of DNA extraction methods for food analysis. Journal of Food Control,18, 76-80.

Di Pinto, A., Marchetti, P., Mottola, A., Bozzo, G., Bonerba, E., Ceci, E., Bottaro, M., \& Tantillo, G. (2015). Species identification in fish fillet products using DNA barcoding. Journal of Fisheries Research, 170, 913

FAO. (2013). Fish identification tools for biodiversity and fisheries assessments. Review and guidance for decision-makers. Ed. Fischer. FAO Fisheries and Aquaculture Department. Rome, Italy. 585. FAO Fisheries And Aquaculture Technical Paper. Retrieved from http//www.fao.org/docrep/019/i3354e/ i3354e.pdf

FAO. (2018). Overview of food fraud in the fisheries sector. FAO Fisheries and Aquaculture Circular FIAM/Circular No. 1165. Food and Agriculture Organization of the United Nations, Rome. Retrieved from http://www.fao.org/3/i8791en/l8791EN.pdf.

FishBase. (2018). Species identification using morphometric measurements. Retrieved from https://www.fishbase.de/Identification/ Morphometrics/centimeters/Index.php

Ganske, F. (2014). UV absorbance DNA quantitation. BMG LABTECH. Rev. 12/2014. Retrieved from https:/ /www.bmglabtech.com/fileadmin/06_Support/ Download_Documents/ApplicationNotes/AN263.pdf

Hsieh, H.S, Chai, T.J, \& Wang, D.F. (2005). Rapid PCRRFLP method for the identification of 5 billfish species. Journal of Food Science, 70, 246-249. 
Hu, Q., Liu, Y., Yi, S., \& Huang, D. (2015). A comparison of four methods for PCR inhibitor removal. Forensic Science International: Genetics, 16, 94-97.

Invitrogen. (2007). Quant-iTTM PicoGreen $®$ dsDNA reagent and kits. Retrieved from http:// probes.invitrogen.com/media/pis/mp07581.pdf

LGC. (2018). DNA Quantification: Comparison of UV Spectrophotometry and PicoGreen Analysis. Retrieved from https://www.lgcgroup.com/ LGCGroup/media/PDFs/services/Extraction/DNAQuantification-Factsheet-LGC.pdf

Maniatis, T.E., Fritsch, F., \& Sambrook, J. (1982). Molecular cloning. A laboratory manual. New York: Cold Spring Harbor Laboratory.

Martinez, I., James, D. \& Loréal, H. (2005). Application of modern analytical techniques to ensure seafood safety and authenticity. FAO Fisheries Technical Paper No. 455. Rome, FAO. 73 pp. Retrieved from http:// www.fao.org/docrep/008/y5970e/y5970e00.htm

Milana, V., Fusari, A., Rossi, A.R., \& Sola, L. (2011). Molecular and morphological identification of an uncommon centrolophid fish. Central European Journal of Biology, 6(3), 440-445. doi: 10.2478/ s11535-011-0016-x.

Pahl, S. (2018). Authenticity for the australian seafood sector: A review of available tools to identify substitution and mislabelling information. Government of South Australia.

Paul, J.H. \& Myers, B. (1982). Fluorometric determination of DNA in aquatic microorganisms by use of Hoechst 33258. Journal of Applied \& Environmental Microbiology,. 43(6), 1393-1399
Promega. (2002). Technical Manual N0.050: Wizard genomic DNA purification kit. Instruction for the use of products: A1120, A1123, A1125 and A1620. Promega Corporation, Madison-Wisconsin. USA. Retrieved from https://ita.promega.com/-/media/files/ resources/protocols/technical-manuals/0/wizardgenomic-dna-purification-kit-protocol.pdf

Ratnasingham, S., \& Hebert, P.D.N. (2011). BOLD: The Barcode of life data system. Molecular Ecology Resources, 11, 941-942, doi: 10.1111/j.17550998.2011.03067.x

Schrader, C., Schielke, A., Ellerbroek, L., \& Johne, R. (2012). PCR inhibitor - occurrence, properties and removal. Journal of Applied Microbiology. 113:10141026.

Trotta, M., Schonhuth, S., Pepe, T., Cortesi, M.L., Puyet, A., \& Bautista, J.M. (2005). Multiplex PCR method for use in Real-Time PCR for identification of fish fillets from grouper (Epinephelus and Mycteroperca species) and common substitute species. Journal of Agriculture Food Chemistry, 53, 2039-2045.

Wasko, A.P., Martins, C., Oliveira, C., \& Foresti, F. (2003). Non-destructive genetic sampling in fish. An improved method for DNA extraction from fish fins and scales. Hereditas, 138, 161-165.

Weder, J.K.P. (2002). Species identification of beans, peas and other legumes by RAPD-PCR after DNA isolation using membrane columns. Lebensm.-Wiss. u.-Technol, 35, 277-283

Zhang, J., \& Hanner, R. (2012). Molecular approach to the identification of fish in the South China Sea. PLoSONE, 7(2), e30621, doi:10.1371/ journal.pone.0030621 